\title{
DETERMINATION OF COPPER AND ZINC IN MINERAL WATERS BY ATOMIC ABSORPTION SPECTROPHOTOMETRY
}

\author{
Tatiana Mitina*, Nadejda Bondarenko, Oxana Bunciuc \\ Institute of Chemistry of the ASM, 3 Academiei str., Chisinau, Republic of Moldova \\ Email: mitina_tatiana@mail.ru,Tel:(37322)739977
}

\begin{abstract}
The content of copper and zinc in mineral waters were determined by atomic spectroscopy with preliminary extraction of metals. Validation of the technique was carried out by the method of standard additions and proved the reliability of analytical data.
\end{abstract}

Keywords: mineral waters, microelements, atomic absorption spectrometry.

\section{Introduction}

Mineral waters are natural groundwater, and its origin is associated with the formation of rocks, and the type, structure and chemical composition of the constituent minerals. The action of natural waters on mineral and mountain rocks is accompanied by processes of leaching, exchange and chemical interaction with gaseous media, hydrolysis, hydration, and leads to the formation of mineral waters of different chemical composition. In this paper we assess the content of trace elements (copper and zinc) in some mineral waters on the market of Moldova.

Some microelements (iron, iodine, copper, manganese, zinc, cobalt, molybdenum, selenium, chromium, tin, vanadium, fluorine, silicon and nickel) are essential for life. Very small quantities or traces of metal ions are required for normal growth and metabolism.

Copper is found in many vitamins, hormones, enzymes involved in metabolism and tissue respiration. Zinc is a cofactor of a large group of enzymes involved in protein and other forms of metabolism. However, high amounts of these metals in mineral waters have toxic effects and are regulated by the Governmental Decision No.934 from 15.08.2007 regarding the sanitary standards of natural mineral waters quality. The content of copper ions in mineral waters should not exceed $1 \mathrm{mg} / \mathrm{L}$, for zinc - $5 \mathrm{mg} / \mathrm{L}$.

Ten samples of mineral water were taken in the experiment.

Table 1 shows the general ionic composition and salinity of the analyzed samples.

Table 1

Ionic composition and mineralization of analyzed samples

\begin{tabular}{|c|c|c|c|c|c|c|c|c|c|}
\hline \multirow[t]{2}{*}{ Nr. } & \multirow[t]{2}{*}{ Type of water } & \multirow[t]{2}{*}{ Country } & \multicolumn{7}{|c|}{ General ionic composition, $\mathrm{mg} / \mathrm{L}$} \\
\hline & & & $\mathrm{Ca}^{2+}$ & $\mathrm{Mg}^{2+}$ & $\mathrm{K}^{+}+\mathrm{Na}^{+}$ & $\mathrm{HCO}_{3}^{-}$ & $\mathrm{Cl}^{-}$ & $\mathrm{SO}_{4}^{2-}$ & mineralization \\
\hline 1 & Izvoraş & Moldova & 85,4 & 27,8 & 256,0 & 634,4 & 39,8 & 320,4 & 1364 \\
\hline 2 & $\begin{array}{l}\text { Varnița } \\
\text { Unicum }\end{array}$ & Moldova & 71,0 & 102,8 & 284,4 & 597,8 & 237,0 & 383,5 & 1508 \\
\hline 3 & Aqualife & Moldova & 145,6 & 85,3 & 292,1 & 683,2 & 83,1 & 712,0 & 1817 \\
\hline 4 & $\begin{array}{l}\text { Gura } \\
\text { Cainarului }\end{array}$ & Moldova & 172,2 & 105,0 & 354,4 & 701,5 & 96,7 & 895,3 & 2290 \\
\hline 5 & Gura Izvorului & Moldova & 149,8 & 46,5 & 77,9 & 584,8 & 21,3 & 176,9 & 1006 \\
\hline 6 & Aqua-Plop & Moldova & 102,7 & 49,0 & 96,7 & 591,5 & 21,5 & 133,0 & 994,4 \\
\hline 7 & Borsec & Romania & 60,1 & 30,4 & 2,8 & 329,4 & - & 9,2 & 431,9 \\
\hline 8 & $\begin{array}{l}\text { Ledianaia } \\
\text { Jemciujina }\end{array}$ & Russia & 32,6 & 10,2 & 7,8 & 115,9 & 10,6 & 36,8 & 213,9 \\
\hline 9 & Esentuchi & Russia & 25,3 & 5,40 & 2271 & 4574 & 841,0 & 220,3 & 7937,8 \\
\hline 10 & Evian & France & 79,7 & 28,0 & 7,25 & 378,2 & 8,78 & 12,8 & 446,7 \\
\hline
\end{tabular}

The contents of copper and zinc were determined by atomic absorption spectrometry. The results obtained during the determination of trace elements concentration by atomic absorption spectroscopy can be affected by the macro-composition of the samples. This applies to the determination of copper and zinc in natural waters, especially since the mineralization in the analyzed samples varies over a wide range from $213.9 \mathrm{mg} / \mathrm{L}$ to 7937.8 
$\mathrm{mg} / \mathrm{L}$. To eliminate the influence of the matrix and increase the sensitivity of the method, we used pre-concentration of acidified samples, followed by extraction of metals to be determined in butyl acetate in the form of a complex compound with the complex generator sodium N, N-diethyldithiocarbamate.

\section{Experimental}

Determination of metals was carried out by atomic absorption spectrophotometer AAS-3 (Germany) in acetylene-air flame.

Concentration by evaporation:

An aliquot of the sample $100 \mathrm{~mL}$ was placed in a $200 \mathrm{~mL}$ heat-resistant glass, $1.0 \mathrm{~mL}$ of concentrated nitric acid was added, and then slowly heated on a hot plate, preventing the sample from spilling. The contents were evaporated to a volume of 3-5 ml, then cooled, and quantitatively transferred into a $10 \mathrm{ml}$ graduated cylinder.

Concentration by extraction:

Pre-evaporated samples (10 $\mathrm{ml}$ of concentrate) were transferred in $100 \mathrm{ml}$ flasks with ground glass stoppers.

The content of the flask was adjusted with distilled water to a volume of 20-25 ml, then $10 \mathrm{ml}$ of $20 \%$ citric acid solution is added in each flask, and a few drops of phenolphthalein. Dilute ammonium hydroxide solution was added until a pale pink color of the indicator appeared. In each solution $5 \mathrm{ml}$ of $0.5 \%$ sodium $\mathrm{N}$, N-diethyldithiocarbamate and $5 \mathrm{ml}$ of butyl acetate were added. The flasks were closed with ground glass stoppers and shaken for 1 minute. After the phase separation, water was added until the organic phase reached the flask neck. The organic phase was used to determine metal concentrations.

Blank samples for the determination of metals were prepared using the same reagents and in the same amounts as in the preparation of analyzed water samples, but replacing the analyzed water with distilled water. Measurement parameters of the atomic absorption spectrometer AAS-3 for metals determination are presented in table 2.

Table 2

Determination parameters on the atomic absorption spectrometer AAS-3

\begin{tabular}{|l|c|c|}
\hline Determined element & Cu & Zn \\
\hline Wavelength, $\mathrm{nm}$ & 357,9 & 213,9 \\
\hline Width of slit, mm & 0,2 & 0,2 \\
\hline Current of the hollow cathode lamp, mA & 5 & 5 \\
\hline Integration time, $\mathrm{s}$ & 4 & 4 \\
\hline Lag time, $\mathrm{s}$ & 5 & 5 \\
\hline Height of the burner, $\mathrm{mm}$ & 8 & 8 \\
\hline
\end{tabular}

Concentrations of copper and zinc were calculated from the calibration curves. To draw these graphics, we prepared the stock standard solution with a concentration of $100.0 \mathrm{mg} / \mathrm{L}$ from a standard sample of a copper ions solution MSO 0523:2003, or zinc ions solution MSO 0032:1998 with a certified value of $1 \mathrm{mg} / \mathrm{cm}^{3}$ and a relative error of less than $1 \%$ with a probability of $0,95 \%$ (Ukraine). From the stock standard solution we prepared the intermediate solution with a concentration of $1.0 \mathrm{mg} / \mathrm{L}$. Working standard solutions were prepared by the method of extraction, like the samples.

For copper and zinc the calibration curve is linear up to $0,05 \mathrm{mg} / \mathrm{l}$. The correlation coefficient for copper is 0,9973, for zinc - 0,9965 . The correlation coefficients indicate a good linearity for both microelements.

\section{Results and discussion}

Table 3 presents the obtained results for the determination of copper and zinc in mineral waters.

Table 3

Results obtained for copper and zinc determination in mineral waters and the standard deviation of the repeatability

\begin{tabular}{|l|c|c|c|c|}
\hline \multicolumn{1}{|c|}{ Sample } & $\begin{array}{c}\mathbf{C u}, \mathbf{m g} / \mathbf{l} \\
\text { (means of five } \\
\text { determination) }\end{array}$ & $\begin{array}{c}\text { Repeatability } \\
\text { standard deviation, } \\
\mathbf{m g} / \mathbf{l}\end{array}$ & $\begin{array}{c}\text { Zn, mg/l } \\
\text { (means of five } \\
\text { determination) }\end{array}$ & $\begin{array}{c}\text { Repeatability } \\
\text { standard deviation, } \\
\text { mg/l }\end{array}$ \\
\hline Izvoraş & 0,0078 & 0,0002 & 0,010 & 0,00065 \\
\hline Varnița Unicum & 0,0077 & 0,00019 & 0,014 & 0,00052 \\
\hline Aqualife & 0,0042 & 0,0002 & 0,0078 & 0,00019 \\
\hline Gura Cainarului & 0,0036 & 0,0005 & 0,0062 & 0,0002 \\
\hline Gura Izvorului & 0,0042 & 0,00021 & 0,0090 & 0,00057 \\
\hline
\end{tabular}




\begin{tabular}{|l|c|c|c|c|}
\hline Aqua-Plop & 0,0060 & 0,00025 & 0,0090 & 0,00060 \\
\hline Borsec & 0,0047 & 0,00018 & 0,0062 & 0,00045 \\
\hline Ledianaia Jemciujena & 0,005 & 0,00021 & 0,0062 & 0,00050 \\
\hline Esentuchi & 0,0074 & 0,00022 & 0,0093 & 0,00068 \\
\hline Evian & 0,0058 & 0,00028 & 0,0160 & 0,001 \\
\hline
\end{tabular}

The limit of detection (LOD) for copper and zinc was $0,001 \mathrm{mg} / \mathrm{L}$. For the determination of the repeatability of the method, copper and zinc were analyzed five times in the same sample.

Validation of the experimental technique was carried out by the method of standard additions. According to the procedure described above, $5 \mu \mathrm{g} / \mathrm{L}$ copper and zinc were introduced in the samples of analyzed water with different salinity, just before the concentration procedure. For this purpose, in $100 \mathrm{ml}$ of sample were introduced $500 \mu \mathrm{lof} 1 \mathrm{mg} / \mathrm{L}$ standard solution of copper and zinc. The results of recovery of copper additives are given in table 4, and the extraction of zinc additives - in table 5 .

Table 4

Validation of the method of copper determination by standard additions method.

\begin{tabular}{|l|c|c|l|c|}
\hline \multicolumn{1}{|c|}{ Sample } & $\begin{array}{c}\text { Mineralization, } \\
\mathbf{m g} / \mathbf{l}\end{array}$ & Introduced, $\mathbf{m g} / \mathbf{L}$ & Determined, mg/L & Recovery, \% \\
\hline Varnița Unicum & 1508 & 0,005 & 0,0049 & 98 \\
\hline Esentuchi & 7937,8 & 0,005 & 0,0052 & 104 \\
\hline Evian & 446,7 & 0,005 & 0,0048 & 96 \\
\hline
\end{tabular}

Validation of the method of zinc determination by standard additions method

\begin{tabular}{|l|c|c|c|c|}
\hline \multicolumn{1}{|c|}{ Sample } & $\begin{array}{c}\text { Mineralization, } \\
\mathbf{m g} / \mathbf{l}\end{array}$ & Introduced, $\mathbf{m g} / \mathbf{L}$ & Determined, $\mathbf{m g} / \mathbf{L}$ & Recovery, \% \\
\hline Varnița Unicum & 1508 & 0,005 & 0,0053 & 106 \\
\hline Esentuchi & 7937,8 & 0,005 & 0,0047 & 94 \\
\hline Evian & 446,7 & 0,005 & 0,0048 & 96 \\
\hline
\end{tabular}

Validation by standard addition method showed that the additive is found within $4 \%$ of the expected magnitude for copper and $6 \%$ for zinc. This demonstrates the absence of losses and influences in the process of concentration for metals determination.

\section{Conclusions}

Atomic absorption spectroscopy was used to identify copper and zinc in ten samples of mineral water with different salinity. To eliminate the influence of the matrix and increase the sensitivity of the method, samples were concentrated prior to the analysis, and identified elements were extracted in the form of a complex compound with sodium N, N-diethyldithiocarbamate. Validation of the method showed absence of any systematic error and, therefore, the used technique for determination of copper and zinc in mineral water provides reliable analytical information.

\section{References}

[1]. Прайс, В. Аналитическая атомно-абсорбционная спектроскопия. Москва, 1976.

[2]. Babaua, Gabriela-Raluca; Stoica, Anca-Iulia; Capota, Petre; Baiulescu, George-Emil. J. Environmental Geology, 2003,45,58-64.

[3]. Stoica, Anca-Iulia; Babaua, Gabriela-Raluca; Baiulescu, George-Emil. J. Materials and Geoenvironment, 2003, $50,1,361-364$.

[4]. ISO 5725-(1-6)-2002 Accuracy (trueness and precision) of measurement methods and results.

[5]. SM SR ISO 8288Ş2006 Calitatea apei. Determinarea conţinutului de cobalt, nichel, cupru, zinc, cadmiu şi plumb. Metoda prin spectrometrie de absorbție atomică în flacără.

[6]. CITAC/Eurachem Guide: Guide for quality in Analytical Chemistry, 2002. 